\title{
Discursive Political Environment in Indonesian Political Parties: A Study on Partai Kebangkitan Bangsa (PKB)
}

\author{
Yeby Ma'asan Mayrudin ${ }^{l}$, Bayu Nurrohman ${ }^{l}$, Wahyu Kartiko Utami ${ }^{l}$, and M Dian \\ Hikmawan $^{l^{*}}$ \\ ${ }^{1}$ Government Department, University of Sultan Ageng Tirtayasa, Indonesia
}

\begin{abstract}
This article examines the Partai Kebangkitan Bangsa (PKB) in terms of discussing environmental issues and their manifestations. In 2005, the party declared itself as the Green Party. Therefore, we examine the existence of environmental issues in the party's vision and mission and the discourse presented by the party elite as well as how the manifestations in the realm of practical politics can be cross-checked on policies or legislation initiated and / or approved by the party elite. In investigating this problem, we use the Political Party Institutionalization theory formulated by Randall and Svasand and operationalize it in the perspective of environmental politics. The methodology used by the author's team is descriptive qualitative. This type of method helps in analyzing descriptive data on the subject matter in this study. As a result, this paper reveals that PKB's discourse and behavior tends to be half-hearted in institutionalizing it as a green party.
\end{abstract}

\section{Introduction}

In many cases, there are many cases where the state neglects environmental welfare in order to achieve economic prosperity, such as development to market capitalism which results in the destruction of the environment in which humans live. This also happens in Indonesia, there are many cases of development that neglect environmental sustainability, one of which is the case regarding the construction of a pulp factory in North Sumatra. This environmental damage often involves community organizations in helping to solve it because of the lack of information and knowledge. As in October 1988, WALHI (Forum for the Environment of Indonesia) filed a complaint against the Government of the Republic of Indonesia before the Jakarta Central District Court on the grounds that it had issued a permit to establish a pulp mill and a concession for forest exploitation in Sibatuloting, North Sumatra, without regard to establishing legislative procedures for environmental impact management and assessment, resulting in forest destruction in Sibatuloting and landslides around the area. Another case related to the environment that is quite hot in Indonesia is regarding the reclamation of Jakarta Bay. Reclamation is an occupation / effort to utilize an area or land that is relatively useless or is still empty and watery to become useful land by drying it [1]. The Jakarta Bay Reclamation itself is

*Corresponding author : dian.hikmawan@untirta.ac.id 
discussed as one of the developments that has resulted in environmental damage because it is considered to have violated the AMDAL (Environmental Impact Analysis) and is dangerous to the ecosystem.

Apart from the two cases above, there are many other cases of development in Indonesia that do not or even pay attention to the environment at all. This of course must be a serious concern for the government as the holder of power in administering public welfare in Indonesia. Sustainable development should be the foundation of development in Indonesia, especially since Indonesia has long implemented the Sustainable Development Goals (SDGs), so development based on the SDGs must be carried out for the sake of environmental welfare but also the welfare of the community in a sustainable manner.

Apart from the role of the government, the role of political institutions, both governmental and non-governmental institutions, also plays a big role in democracy, especially in Indonesia where there have been many environmental observer organizations, such as WALHI, which is often involved in cases involving environment in Indonesia [2], [3]. However, the role of formal state institutions must also be considered because they also have an important role, especially since they have closer access to the government. Political parties as intermediary actors that connect society and the government are important actors, not only on the political stage, but also in relation to the environmental agenda which is often neglected by the government as the holder of power.

As one part of the political infrastructure, political parties are not in a position to be able to determine and determine policies directly, but in practical politics, political parties are able to exert great influence and pressure on how policies in the state can be determined. Parties have representatives in parliament so that they are able to exert pressure so that all forms of policies discussed in parliament are able to implement the values and agendas of political parties in the interests of society and environmental issues. Political parties also have a role in political contestation, so that their influence is still very pronounced in the executive dimension. These influences are able to be utilized by parties to pressure the executive and legislature to always produce good performance and produce policies that are always pro-society and the environment. This condition illustrates that in protecting and preserving the environment, political parties actually have a very big role in being able to determine the direction of policy.

So far, cases of environmental damage tend not to be a major concern for parties and elites. It can be seen how infrastructure development from the start of the reformation until now has neglected aspects of natural conservation [4]. This means that parties that actually have cadres in parliament have not optimally carried out checks and balances related to environmental issues. So the fundamental question arises about what and how the role of political parties in Indonesia in environmental issues? Until now, research on party activism with an environmental political perspective has developed abroad such as research by McCulloch [5], Carter [6], Noji [7], Muller-Rommel [8], and others. However, there are still few research studies in Indonesia regarding this matter, such as those of Rahmah [9] and Supratiwi [10] which are still limited to empirical but non-conceptual justifications (organizing or institutionalizing parties). So in this paper we try to use the concept of party institutionalization and modify it by instilling an environmental political perspective to see the extent to which the Partai Kebangkitan Bangsa (PKB) calls itself a green party, which means supporting the movement for environmental protection and preservation in practice like what in practice. field. We made this party the object of research because since 2005 it has declared itself the first green party in Indonesia. PKB's commitment to making green politics as a political attitude and agenda is very interesting to analyze with this modified framework so that this research has its uniqueness and urgency in developing issues and theories. 


\section{Theoretical Framework}

\subsection{Environmental Politics}

Environmental politics is a political discursive about natural resource management. The scope of environmental studies in environmental politics, such as forest destruction, mining exploitation, damage to the urban environment due to unbalanced development, air pollution, factory waste, river pollution, sanitation and so on. There are several concepts that can be used to understand environmental politics, one of which is the study of ecological politics. Political ecology began to develop in the late 1970s and early 1980s. The term ecology itself is actually a concept that describes the relationship between humans and their environment.

Watts [11] defines ecological politics as "to understand the complex relationship between nature and society through careful analysis of what may be called forms of access to and control over resources and their implications for environmental health and sustainable livelihoods". The purpose of ecological politics itself is to explain environmental conflicts, especially conflicts related to knowledge, justice and governance. Using Watts' definition above, environmental politics can be defined as an instrument to understand the complexities of having access to and control over resources and their impact on environmental health and sustainability [26].

In the political context, Yakop [13] stated that protection of the environment would be an agenda option if the existing democratic climate provided room for environmental issues to occupy a priority agenda. But unfortunately, in the practice of democratization, including in Indonesia, it does not necessarily make environmental issues become the main agenda. In some cases, the implementation of democratization sometimes has the potential to neglect the environmental agenda.

However, there are also democracies that have moved towards green democracy or democracy that is pro to environmental issues. The priority of environmental issues usually grows along with the conflicting discourses presented by scientists with the support of environmental activists and the 'green democracy movement' or what can be referred to as the ecodemocracy or biocracy [27], which carry out institutional and practical innovations that demand sustainability of environmental and the democratic atmosphere that guards it. This pro-environment democracy grows and is faced with a variety of new demands, all of which lead to everything that is sensitive to the environment. From building a political system that is environmentally sensitive (green policies) with the support of spiritualasceticism that reminds us that there is life after death and that there is cause-and-effect, reward and punishment. In addition, there are parties that are environmentally sensitive and make the environment their main platform (green party) [13].

In environmental politics, the political leadership factor determines the effectiveness of regulations on sustainable natural resource management. Natural resource management regulations and policies are adaptive to political leadership. On that basis, it is appropriate for the political elite, especially the party elite, to develop an environmental political perspective in their respective party institutions or organizations. It is hoped that in order to preserve nature and avoid the impact of environmental damage.

\subsection{Party Institutionalization}

Political parties are intermediary actors, namely as a liaison actor that bridges the community and the government as the holder of power. In addition, its function is also central in a democratic country [15]. With the opening of the faucet of Indonesian political 
freedom in the reform era, the number of political parties in Indonesia is increasingly unstoppable. So that until now there have been dozens of political parties that have enlivened the political scene in Indonesia, as a result the party system in this country is considered to be extreme multiparty [28].

The fall of political parties in Indonesia since the start of the liberalization of party politics in 1998 until now is an interesting phenomenon to discuss. The main problem that causes these parties to die or disappear from politics is due to the fragility of the institutionalization of their party organizations [29]. Therefore, several scholars offer formulations regarding the institutionalization of political parties that aim to stabilize a party in order to win elections and survive.

Some scholars who have explored this topic are Huntington, Panabianco, Levinsky, and Randall \& Svasand. When referring to Huntington [18], institutionalization is defined as "the process by which organizations and procedures obtain standardized and stable values." Political parties experience growth and development. He noted that the growth of political parties goes through a number of phases: Starting with the birth of the party and possibly ending with the death of the party, or from a pro-party to a political party that stops at a certain phase for a very long period of time, or a political party does not develop into a proper party so that it fails to become a perfect party entity.

Furthermore, Randall and Svasand [18] stated that "Institutionalization should be understood as the process by which the party becomes established in terms both of integrated patterns of behavior and of attitudes, or culture." Therefore, they offer the concept of party institutionalization which contains two aspects, namely internal-external and structural-attitudinal aspects, as follows:

Table 1. Dimensions of Party Institutionalization

\begin{tabular}{|l|l|l|}
\hline & Internal & External \\
\hline Structural & Systemness & Decisional autonomy \\
\hline Attitudinal & Value infusion & Reification \\
\hline
\end{tabular}

Source: Randall dan Svasand [18]

The internal aspect refers to the development within the party itself, while the external aspect relates to the party's relationship with society, including other institutions, but not limited to other parties. The combination of aspects that have been mentioned and will be narrated in the future, then we instill the perspective of Environmental Politics to harmonize with our framework. As explained as follows:

First, the structural aspect of the party's internal dimension is called systemness. The point is the process of establishing the scope, cohesiveness, and regularity of interactions that make the party a structure. Regularity means the level of routine and habit development that is considered commonplace and becomes a behavior guide in party organizations. In this article, the degree of systemness is measured based on how the presence of environmental political discourse in the Vision Mission, article of the association/bylaws, and other party documents. We call this fusion of systemness - environmental politics with the term eco-systemness.

Second, the infusion value. This concept refers to the extent to which party actors and their supporters identify and have a commitment to the party so as to create a value system that becomes the glue between the two. The identity of a party's value is based on the party's ideology or platform, the social basis of its supporters and the identification of members of the pattern and direction of the party's struggle. In the context of this research, it is measured by whether the party cadres in carrying out the procedures and party rules have embodied the perspective of environmental politics. How the actions of party cadres reflect the values of environmental political struggle beyond personal and other political interests. In this modified dimension we give the term eco-value infusion. 
Third, decisional autonomy. This dimension relates to the party's relationship with actors outside the party, with certain authorities (government) as well as sources of funds (entrepreneurs or external institutions) and sources of mass support. The most important thing from this dimension when including the perspective of environmental politics is: The relationship between parties and institutions outside the party does not affect independence in the environmental political policy process. We call it eco-decisional autonomy.

Fourth, reification. Namely, how the existence of a party is embedded in the minds or imagination of the people, or the extent to which political parties with their characteristics are recognized and recognized. Reification is intended so that the party is able to raise the loyalty of constituents in providing support. If the existence of a certain political party is embedded in the public's imagination, then they will adjust their aspirations and hopes or attitudes and behavior to the existence of that party. Reification has a lot to do with the symbolic politics that parties play, the party's populist platform and the implementation of its platform. In the context of this research, we associate the perspective of environmental politics with indicators such as: The image of the public and / or cadres of the party as a green party, not a personal entity; Public acceptance and / or cadres of their identity as a green party are different from other parties. We give the term modification the name ecoreification.

Below is a table of the modified model of party institutionalization theory instilled in an environmental political perspective:

Table 2. Modification of Party Institutionalization by Inculcating an Environmental Political Perspective

\begin{tabular}{|c|l|ll|}
\hline No & Dimension & \multicolumn{1}{|l|}{ Indicator } \\
\hline 1 & Eco-Systemness & $\begin{array}{l}\text { a. } \\
\text { How is the presence of environmental political discourse in the } \\
\text { Vision and Mission, article of the association/bylaws, and other party } \\
\text { documents }\end{array}$ \\
\hline 2 & $\begin{array}{l}\text { Eco-Value } \\
\text { Infusion }\end{array}$ & $\begin{array}{l}\text { a. } \\
\text { b. }\end{array}$ \\
$\begin{array}{l}\text { Party cadres in implementing party procedures and rules have } \\
\text { The actions of party cadres reflect the values of environmental } \\
\text { political struggle beyond personal and other political interests. }\end{array}$ \\
\hline 3 & $\begin{array}{l}\text { Eco-Decision } \\
\text { Autonomy }\end{array}$ & a. & $\begin{array}{l}\text { Relationships between parties and institutions outside the party do not } \\
\text { affect independence in the environmental political policy process. }\end{array}$ \\
\hline Eco-Reification & a. & $\begin{array}{l}\text { Public and / or cadre image of the party as a green party, not a } \\
\text { personal entity. } \\
\text { Public acceptance and / or cadres of their identity as a green party are } \\
\text { different from other parties. }\end{array}$ \\
\hline
\end{tabular}

Source: Modification of Randall and Svasand's theory by the Writing Team

\section{Result and Discussion}

\subsection{The emergence and development of PKB as the Nahdhiyin Party}

PKB was declared on 23 July 1998 in Jakarta. It is common knowledge that the party was born from the womb of NU with the main pioneer is Abdul Rahman Wahid (Gus Dur). Its establishment by NU was an attempt to overcome two major trends that emerged in the post-New Order NU. One other group is wanting NU to remain a religious mass organization. The solution is for NU to help establish parties to facilitate and articulate the interests of NU citizens without making NU a political party. Thus, the relationship 
between NU and PKB is historical, cultural and aspirational. Historically, it means that the formation of PKB is closely related to NU. Cultural means that the PKB struggle must pay attention to the unique cultural environment adhered to by NU, namely the cultural environment formed by the Islamic religious values of Ahlussunnah wal Jama'ah. Meanwhile, aspirational means that PKB is obliged to fight for the political ideals of NU citizens [19].

For this reason, the steps taken by the NU Executive Board (PB) are quite strategic. The manager of the jam'iyyah NU is of the opinion that NU will remain as jam'iyyah diniyah ijtimaiyah, not a political party, and that no one will establish a political party. Nevertheless, the PBNU allowed Nahdhiyin residents to establish a party of origin done conceptually and through careful considerations. NU politics must be placed in a subordinate position, not in an ordained position. This placement will make jam'iyyah NU have two movements at once. A number of congregations carried out political movements through the formation of political parties, other congregations and NU's own jam'iyyah remained consistent with the 1926 khitthah [19].

Towards the implementation of the 1999 election, PKB continued to prepare everything carefully, including establishing the ideological principles of the party in the article of the association/bylaws. The Partai "sembilan bintang", oddly enough, confirmed Pancasila as the ideological principle of the party. This is different from the Partai Keadilan (PK) and the Partai Bulan Bintang (PBB) which clearly wrote Islam as its ideological principle. However, Mayrudin [28] emphasized that the PKB classification is still included in the category of Islamic parties because the main basis comes from NU and based on its distinctive religious values, namely Divinity and Ahlussunnah wal Jama'ah which are contained in the party's statutes.

In the domain of electoral competitions as election participants, PKB experiences fluctuations in vote acquisition. In the 1999 election, as a new party, PKB was classified as successful, because it won third place in the national vote acquisition, winning 13,336,982 votes. However, the party's mass support base was limited to Java. Because almost $90 \%$ of the votes came from Java. And what is interesting and unique is that this party has the strong support of rural voters. A character that is suitable as a party for the nahdhiyin residents, most of whom are in rural areas. Unfortunately, in the 2004 and 2009 elections, this party experienced a decline of up to 2 million votes and the most risky thing is that it lost 8 million votes due to internal conflicts. In the 2014 election, this party experienced a fantastic increase in the number of votes that were around 6 million. From 5,146,122 votes, it increased to $11,298,957$ votes. Even in this election, PKB got quite a big vote in East Java, which is its main base. As we know, that area is an area with a number of elderly kiai and nahdhiyin residents who are the main supporters of PKB. The glory of this party continues to be seen with the number of votes that increased by 2 million votes in the 2019 elections [19].

\subsection{Declaration of PKB as Green Party}

The work of PKB in Indonesian politics is always interesting to analyze. This party is one of the parties whose existence is still maintained today. Even more amazing, PKB always succeeded in exceeding the parliamentary threshold which made them always have representatives in parliament. The existence of PKB is never separated from the party's agendas which are interesting to observe. The party agenda is determined, of course, not without political interests, there must be a segmentation of society that becomes the target of implementing this agenda. The PKB agenda that attracts attention is to declare itself a 
green party. PKB stated that they had declared themselves a green party since 2005 [20], another version was declared in 2007 by Gusdur [21]. This attitude was taken by the party because it had begun to worry about massive environmental damage that would result in global warming and increase the potential for natural disasters.

The interests of PKB are of course not only limited to participating in protecting the environment but there is another agenda, namely attracting sympathizers from the community who also have the same interest in environmental protection. In its implementation as a green party, there were inconsistencies in several incidents, such as in 2007 PKB gave recommendations to the government to determine the Lapindo mud case as a national natural disaster which would have an impact on the responsibilities that would later be given to PT. Lapindo is not too big. This attitude received a strong response from WALHI who insinuated PKB and even called it a party that was not worthy of being called a green party [22]. Conflicts of political interest in environmental politics have indeed often occurred and are sure to disrupt the PKB agenda as a green party. In the midst of many people's doubts about their commitment as a green party, at the results of the 6th Congress in 2019, this party strengthened their commitment as a green party by emphasizing the struggle agenda with a green political perspective as a precondition for the realization of sustainable development based on the values of rahmatan lil alamin [23].

\subsection{Institutionalization of PKB in the Perspective of Environmental Politics}

In this section, we try to analyze PKB discourse and political behavior by using a modified party institutionalization theory with an environmental political perspective (ecosystemness, eco-value infusion, eco-decisional autonomy, and eco-reification).

First, eco-systemness: In order to know the degree of this dimension, it is necessary to analyze the vision and mission, statutes / articles of association and the basic values of the party's struggle. PKB has a vision: "Realizing the ideals of independence of the Republic of Indonesia as outlined in the Preamble to the 1945 Constitution; Creating a just and prosperous society physically and mentally, materially and spiritually; and Realizing a national political order that is democratic, open, clean and has good morals. " In connection with the textual "environment", it can be seen that diction is not used as a keyword in the editorial vision of the party. While the Mission and also in the statutes / articles of association of PKB are also editorial of Ecology, the concept of environmental / environmental sustainability or green politics is not listed. However, referring to Priyo Pamungkas (Deputy Secretary of DPW PKB DKI Jakarta 2015-2021) in the interview, he stated that implicitly environmental issues have been contained in Mabda 'Siyasi by emphasizing "solving social problems" as an umbrella for environmental issues. In addition, at the PKB Congress VI in Bali on August 20-21 2019 which resulted in the "Bali Declaration" regarding 9 (nine) PKB attitudes, one of which is "Green Politics, strengthening $\mathrm{PKB}$ by promoting politics with an environmental perspective as a prerequisite for sustainable development. " Thus, basically the value of PKB's attitude is an affirmation of being a Green Party. The existence of this attitude is also an effort to convince the public of their commitment as a party that cares for the environment. However, in its embodiment of political behavior, PKB tends not to have seen many significant actions capable of improving environmental problems in this country, especially the actualization of "green" practices in every government policy.

Second, eco-value infusion. So far in implementing the Green Party concept, cadres have taken several concrete steps such as those raised by PKB administrators at the local level. In August 2017, Muhaimin Iskandar together with 1,500 UKM players planted 19,000 trees on the slopes of Mount Slamet. This event is entitled "Nusantara Menanam" which is also part of the party's agenda to emphasize attention and concern for the 
environment. This event seemed to re-emphasize the spirit of the party and cadres in protecting the environment by creating a good ecosystem in protecting the environment [24]. In March 2021, DPC Tual City, carried out a mangrove tree planting movement on Taar Beach. This activity was also appreciated by the Tual City Government, because it was a movement that showed PKB's commitment as a party that cares about the environment, especially this activity will also take place in other areas in Maluku [25]. At the DPW level, Maluku Province has also planted 2,500 mangrove saplings. In addition, the PKB cadre who is also a member of the Indonesian Parliament Maman Imanulhaq initiated the "Subang Kota Hijau" (Subang as Green City) declaration to emphasize the role of cadres in environmental sustainability [26]. Obviously all of this is done in order to provide evidence to the public about the commitment they are making, namely as a party that is responsible for preserving the environment. This is something that we should appreciate. However, as a large party that has power in the parliament and the executive, it should not only be limited to socialization and ceremonial purposes, but should be able to realize laws or government regulations that support green or environmental programs.

Third, eco-decisional autonomy. Several things that need to be underlined and taken into account are how the PKB's attitude when the agenda for environmental protection collides with the political interests of the government or other parties who have great influence, whether they are still trying to fight as a green party or choose apathy at certain times because they are considered too risky if you put up a fight. In this part, the actual image of PKB as a Green Party is starting to be doubted. In 2007, Walhi said that PKB was not worthy of being called a Green Party. This is because FKB DPR recommended the government to determine the Lapindo mud case as a national natural disaster. In fact, the mudflow is actually an ecological disaster caused by corporate activities. PKB should feel that it is one of the parties that supports the conservation and environmental protection movement, not providing recommendations for natural disasters so that full responsibility is still held by PT. Lapindo. This recommendation gives rise to the view that there are political interests that cannot be avoided by PKB so it is necessary for them to do so. And this step shows that at that time environmental interests could still be influenced by external political interests. However, over time, PKB continues to improve its prestige as a green party. In 2014 PKB began campaigning against perpetrators of environmental destruction and invited all its cadres to fight against all forms of damage to the environment because it would have the potential to cause natural disasters. This campaign seems to be obliged to be heeded by its cadres, in July 2020, the DPW PKB NTT took action to condemn all forms of damage that occurred at Mingar Beach. This action was carried out because it was to support the party's agenda, namely to participate in preserving the environment.

Fourth, eco-reification: In this context the research team conducted a search for PKB administrators or cadres and the millennial generation regarding their images related to the green party stamp of the PKB. Priyo as a PKB millennial cadre emphasized that PKB's imagination as a Green Party is different from the context with the concept of other countries. Green PKB is more from an Indonesian, populist side, and as an advocacy party on environmental issues such as fisheries, marine, plantations, forestry and climate change. Unfortunately when interviewing several millennial generations who are students, namely Ahmad Riyan, Ferliana, Wawan, and Mahfudotullah, their images of PKB are the NU party, the Kiai party, the Moderate Islamic Party, the party supporting the government. Some even mentioned the name Muhaimin Iskandar as an image that occurred to one of the student. This means that the PKB image among the millennial generation is not a Green Party but is attached to the image of a Nahdliyin party. Therefore, the institutionalization of PKB as a Green Party is still not accepted, even not known by many young people. 


\section{Conclusion}

As a political agenda in the Indonesian party, PKB tries to engage on environmental issues through the formal-legalistic policy. It becomes the new one for Indonesian party to scaling up the environment to public discourse in Indonesia. As apolitical agenda. PKB has a strong potential to influence policy discussing on the parliament about environmental sustainability. Illegal logging, the land conversion, and the wide of environmental governance. PKB also attracting the environmental issues to around the political party agenda in Indonesia. It becomes a big point and the challenge for all the political party in Indonesia. How much the politician concern and giving attention to the environmental sustainability in Indonesia.

However, if we look at PKB's discourse and political behavior related to environmental and green party issues by using a modification of the theory of Party Institutionalization and Environmental Politics, it is revealed that the institutionalization of these parties is still half-hearted as a Green Party. First, the dimension of eco-systemness has a half degree because in the vision and mission, party regulations, and Mabda 'Siyasi are not rigidly contained in the terms ecology, "environment," and "green", but only in the "Bali Declaration". Second, eco-value infusion, the degree is half because PKB is limited to carrying out socialization which tends to be ceremonial. But there is something even better for this party, namely advocacy. However, PKB has not been able to implement laws or government regulations that support green or environmental programs. Third, ecodecisional autonomy, the degree is half because in the case of PT Lapindo, PKB does not take the interests of the environment, its political behavior tends to be influenced by external political interests. However, starting in 2014, the party began campaigning against perpetrators of environmental destruction and inviting all its cadres to fight against all forms of destruction to the environment. Fourth, eco-reification, the image of PKB among the millennial generation is not a Green Party but is attached to the image of a Nahdliyin party. On the basis of the findings of these four objective conditions, the institutionalization of PKB as a Green Party has not been fully discussed and practiced by the parties, elites and their cadres.

\section{References}

1. A. Bintari, CosmoGov 4, 119 (2018)

2. H. N. Efendi, Y. Yulianto, and I. Prihantika, Adm. J. Birokrasi, Kebijak. Dan Pelayanan Publik 1, 19 (2019)

3. R. F. Yani, Asrinaldi, and D. Rahmadi, JDPL (Jurnal Demokr. Dan Polit. Lokal. I, 88 (2019)

4. B. Wiwoho, CNN Indones. (2017)

5. A. McCulloch, The Ecology Party and Constituency Politics: The Anatomy of a Grassroots Party (1983)

6. N. Carter, Party Polit. 12, 747 (2006)

7. K. Noji, Shinshu Univ. Law Rev. 1, (n.d.)

8. F. MÜLLER-ROMMEL, Ecology (1994)

9. S. R. Rahmah, Komitmen Partai Kebangkitan Bangsa Sebagai Partai Hijau: Studi Kasus Partai Kebangkitan Bangsa Dewan Perwakilan Cabang Kota Surabaya, Airlangga University, 2019

10. Supratiwi, (2015)

11. V. R. Siahaan, Politik Lingkungan Indonesia: Teori \& Studi Kasus (UKI Press, Jakarta, 2020) 
12. M. D. Hikmawan and R. Hidayat, J. Gov. 1, 23 (2016)

13. R. M. Yakop, S. \& Rozi, and A. Abdullah, A Caleidoscope of Environmental Security: Indonesian and Malaysian Perspectives (Madani Press, Jakarta, 2009)

14. I. Naisyah and T. Aisyah, Int. J. Demos 1, 290 (2019)

15. A. Primadi and T. Purwaningsih, J. Gov. Civ. Soc. 3, 63 (2019)

16. Y. M. Mayrudin, J. Gov. 2, 163 (2017)

17. N. I. Harun, J. Gov. 4, 171 (2019)

18. V. Randall and L. Svåsand, Party Polit. 8, 5 (2002)

19. Y. Mayrudin and M. C. Akbar, in (2019), pp. 283-288

20. PKBNews, Pkb.Id (2019)

21. U. S. Kamal, Pepnews.Com (2019)

22. DetikNews, (2007)

23. Fraksi PKB, (2019)

24. H. Aco, Tribunnews.Com (2017)

25. M. Maturbongs, Rri.Co.Id (2021)

26. F. Aristama, RMOL.ID (2020) 